\title{
Modulation of Postprandial Glucose Bioavailability in a Cohort of Healthy and Pre-Diabetics Subjects during Ramadan Fasting in Côte d'Ivoire
}

\author{
Jacko R. Abodo1 ${ }^{*}$, Jean B. Gbakayoro², Kouakou Brou², Georges G. Tiahou ${ }^{3}$, Adélaïde Hué1, \\ Assita Yao ${ }^{1}$, Jocelyne Danho', Adrien Lokrou ${ }^{1}$ \\ ${ }^{1}$ Office of Endocrinology Diabetes Nutrition, CHU Yopougon, Abidjan, Côte d'ivoire \\ ${ }^{2}$ Laboratory of Nutrition and Food Safety, Faculty of Science and Food Technology, \\ University Nangui Abrogoua, Abidjan, Côte d'Ivoire \\ ${ }^{3}$ Laboratory of Biochemistry, Medical Sciences Faculty, University Alassane Ouattara, Bouaké, Côte d'Ivoire \\ Email: *sfadabidjan@yahoo.fr
}

How to cite this paper: Abodo, J.R., Gbakayoro, J.B., Brou, K., Tiahou, G.G., Hué, A., Yao, A., Danho, J. and Lokrou, A. (2017) Modulation of Postprandial Glucose Bioavailability in a Cohort of Healthy and PreDiabetics Subjects during Ramadan Fasting in Côte d'Ivoire. Open Journal of Endocrine and Metabolic Diseases, 7, 127-139. https://doi.org/10.4236/ojemd.2017.75012

Received: May 1, 2017

Accepted: May 28, 2017

Published: May 31, 2017

Copyright $\odot 2017$ by authors and Scientific Research Publishing Inc. This work is licensed under the Creative Commons Attribution International License (CC BY 4.0).

http://creativecommons.org/licenses/by/4.0/

\begin{abstract}
Objective: After the Ramadan fasting period, there is an increasing prevalence of diabetes in Côte d'Ivoire, in diabetes care centers. The objective of this study was to assess the consumption of sugary foods during this period and to determine the risks of diabetes in Muslim populations. Methods: Information was collected on the type and amount of sugary foods consumed. Methods for the preparation of these foods have been determined. Intake frequencies and postprandial glycemic responses were studied. The usual statistical methods were used. Results: Between $70 \%$ and $85 \%$ of the "fasters" consume plenty of these sugary foods during this period, with an average added sugar level varying between $10 \%$ and $35 \%$ and a daily consumption of between $250 \mathrm{cl}$ and 0.5 1. The added sugar leads to hyperglycemia in both healthy subjects and pre diabetics. Conclusion: Regular consumption of these sugary foods results in significant hyperglycaemia throughout the month of fasting with a significantly higher blood glucose level in pre diabetic subjects. This makes pre diabetics people more at risk of diabetes among Muslim populations during Ramadan fasting.
\end{abstract}

\section{Keywords}

Ramadan Fasting, Postprandial Glucose, Pre Diabetes 


\section{Introduction}

Fasting during the month of Ramadan is the most observed religious ritual by Muslims. It is characterized by a water and energy deprivation from dawn to sunset, which varies from 12 to 18 hours throughout the "sacred month" [1]. The month of Ramadan comes without transition and practitioners suddenly change their lifestyle [2]. These changes are observed in dietary habits, sleep time and physical activity [3] [4]. The food intake becomes exclusively nocturnal with an overconsumption of sugary and fatty products. These changes in feeding behavior affect metabolism, particularly dehydration, hypoglycaemia and nocturnal hyperglycaemia. Also, the prevalence of diabetes in Muslim countries is higher. Indeed, it has been shown by [5] and [6], a prevalence of $10 \%$ of diabetes in the countries of the Arab Maghreb; 10.9\% in the Middle East; 13.7 per cent in Saudi Arabia; $8.7 \%$ in South-East Asia (home to nearly $62 \%$ of the Muslim population) against a global prevalence of $6 \%$. In Côte d'Ivoire, a country that is also home to a Muslim population; during the fasting of the month of Ramadan, there is an increased consumption of sugary foods. The objective of this study was to evaluate the influence of the consumption of sugary foods on the postprandial glycemia of Muslims in Côte d'Ivoire during the month of Ramadan.

\section{Material and Methods}

\subsection{Biological Materials}

The biological material used in this study consisted in the material used to make the sweet foods studied. These include Hibiscus sabdariffa chalices, ginger rhizomes (Zingiber officinale), millet grains (Panicum miliaceum), corn kernels (Zea mays), millet and sweet banana (Musa sapientum) respectively for the preparation of "bissap infusion", "gengimbre juice", millet porridge, corn porridge, millet fritters called "womi". These foods were purchased from the markets of Abobo and Adjamé, in the district of Abidjan in Côte d'Ivoire

\subsection{Methods}

\subsubsection{Framework for the Study}

The study on the consumption of sweet foods (Study 1) was conducted in 20 mosques in Abidjan (Port Bouet, Koumassi, Plateau, Adjamé, Abobo, Cocody, Riviéra) and 10 mosques (Anyama, Yamoussoukro, Abengourou, Daloa, Gagnoa, Bouake, Korhogo, San Pedro). The experimental study on postprandial glycemia of sweet foods (Study 2) was conducted at the Nutrition Laboratory of Nangui Abrogoua University.

\subsubsection{Type and Period of Study}

Two types of study have been carried out. This is a prospective descriptive study for Study 1, which took place in the fasting months of Ramadan in 2012, 2013 and 2014 precisely during the periods from 20 July to 19 August 2012, from 9 July August 8, 2013, June 29 to July 28, 2014, and a comparative cohort study for Study 2 that ran for a 2 week period from March 7 to 21, 2014. 


\subsubsection{Study Population}

Study 1 was carried out on the basis of a questionnaire given by 653 people, consisting of fasted people and women selling these sweet foods in the vicinity of the mosques. Included were nationals, aged 18 to 65 years. Study 2 was conducted with two groups of 10 volunteers, aged between 18 and 40 years, healthy and pre diabetic.

\subsubsection{Course of the Study}

Study 1:

Using a "24-hour dietary recall" questionnaire and a questionnaire on the frequency of food consumption by the weekly method, information on food consumption was collected. The information is related to the nature, order, quantities and frequencies of consumption of sugary foods. Methods of preparation of these dishes have also been detailed.

Study 2:

For the determination of the postprandial glycemic response of the foods studied, two groups of 10 volunteers, regardless of sex between 18 and 40 years of age, were recruited. On the day of the test, subjects had been fasting for 12 hours and were taken to consume average amounts of food consumed during the Muslim fast, as determined by the previous survey. To get into the fasting conditions, the various subjects were asked not to practice unusual physical activity and to keep a normal diet. The first measurement $t=0$, of the capillary blood glucose was carried out before the ingestion of the meal. Then the calm subjects ingested the food with $250 \mathrm{ml}$ of water for solid foods (womi, dates), without adding water for semi-liquid foods (millet porridge, maize porridge) and liquids (Ginger juice, bissap juice). Capillary samples were taken at $\mathrm{t}=15$ $\mathrm{min}, 30 \mathrm{~min}, 45 \mathrm{~min}, 60 \mathrm{~min}, 75 \mathrm{~min}, 90 \mathrm{~min}, 105 \mathrm{~min}$ and $120 \mathrm{~min}$. The energy requirements of the individual subjects in the study were then calculated by taking into account the age (in years), weight (in $\mathrm{kg}$ ), size (in $\mathrm{m}$ ), physical activity level Individual according to the formulas of Harris and Benedict modified by Roza and Shizgal (1994): This was done in two steps:

Step 1: Calculation of 24-hour basic energy expenditure:

1) Man $=13.707$ * Weight $(\mathrm{kg})+492.3 *$ Size $(\mathrm{m})-6.673$ * Age (years $)+77$. 607

2) Woman $=9.740 *$ Weight $(\mathrm{kg})+172.9 *$ Size $(\mathrm{m})-4.737$ * Age (year $)+$ 667.051

Step 2: Calculation of energy requirements for 24 hours:

3) Sedentary men and women = Basic metabolism (resting energy expenditure $=$ DER $)^{*} 1.375$

4) Active male and female $=$ Basic metabolism (resting energy expenditure $=$ $\mathrm{DER}) * 1.55$

\subsubsection{Data Collection and Analysis}

Data have been collected from survey forms. For the proportion comparison, $t$ 
tests were applied between the values obtained. The significance level was set at $5 \%$.

\section{Results}

\subsection{Characteristics of People Who Participated in Ramadan Fasting}

Among those surveyed, $6.12 \%$ were already known to be diabetic (Table 1). The average energy requirements of men were $2678 \pm 103 \mathrm{kcal} /$ day and those of women, of $2016 \pm 98 \mathrm{kcal} /$ day. Several populations at risk of diabetes were fasting, $39.50 \%$ of whom had a family history and $8.26 \%$ had pre-diabetes.

Frequency of consumption and proportions of the most consumed sugary foods.

Sweet, sugary, sugary liquid foods have been consumed extensively (Table 2). Bissap infusion, ginger juice, coffee and tea are the main sweetened liquid foods consumed by $75 \%, 60 \%, 70 \%$ and $45 \%$ of young people, respectively, in amounts ranging from $250 \mathrm{cl}$ to $0.5 \mathrm{~L}$ and $10 \%$ to $35 \%$ of added commercial sugar. The millet and corn porridge were the most consumed sweetened semi-liquid foods by $85 \%$ and $30 \%$ of young people respectively in quantities of $250 \mathrm{cl}$ with $15 \%$ to $20 \%$ of added commercial sugar. The "womi" and dates were the most consumed sweetened solid foods, each at least by $85 \%$ of the young. On average, 10 units of "womi" versus 2 units of dates were consumed.

\subsection{Postprandial Blood Sugar Sweet Foods}

There is a significant interaction between the type of sweet food ingested and the time of the glycemic response (Figure 1). This is reflected in the difference in the kinetics of glucose induced by the two juices in the periods from 0 to 30 minutes

Table 1. Some characteristics of persons involved in the Muslim fasting in Côte d'Ivoire from 2012 to 2014 .

\begin{tabular}{|c|c|c|c|c|c|c|c|}
\hline & \multicolumn{3}{|c|}{ Family past history } & \multicolumn{4}{|c|}{ Personal past history } \\
\hline & Obesity & Diabetes & Hyper-tension & (kcal/day) & $\begin{array}{c}\text { Normal } \\
\text { blood } \\
\text { sugar }\end{array}$ & Prediabetic & Diabetic \\
\hline Men & 159 & 58 & 107 & & 358 & 34 & 23 \\
\hline$(\mathrm{n}=425)$ & & & & $2678 \pm 103$ & & & \\
\hline percentage & $37.41 \%$ & $13.64 \%$ & $25.17 \%$ & & $84.23 \%$ & $08.00 \%$ & $05.41 \%$ \\
\hline Wwomen & 99 & 43 & 72 & & 201 & 20 & 17 \\
\hline$(\mathrm{n}=228)$ & & & & $2016 \pm 98$ & & & \\
\hline Percentage & $43.42 \%$ & $18.85 \%$ & $31.57 \%$ & & $88.15 \%$ & $08.77 \%$ & $07.45 \%$ \\
\hline Grand Total & 258 & 101 & 179 & & 559 & 54 & 40 \\
\hline$(\mathrm{n}=653)$ & & & & $2347 \pm 101$ & & & \\
\hline Percentage & $39.50 \%$ & $15.46 \%$ & $27.41 \%$ & & $85.60 \%$ & $08.26 \%$ & $06.12 \%$ \\
\hline
\end{tabular}

Family history of obesity: a person with at least one obese parent; Family history of diabetes: person with at least one diabetic parent Family history of hypertension: person aged hypertensive parents; E N: energy needs. 

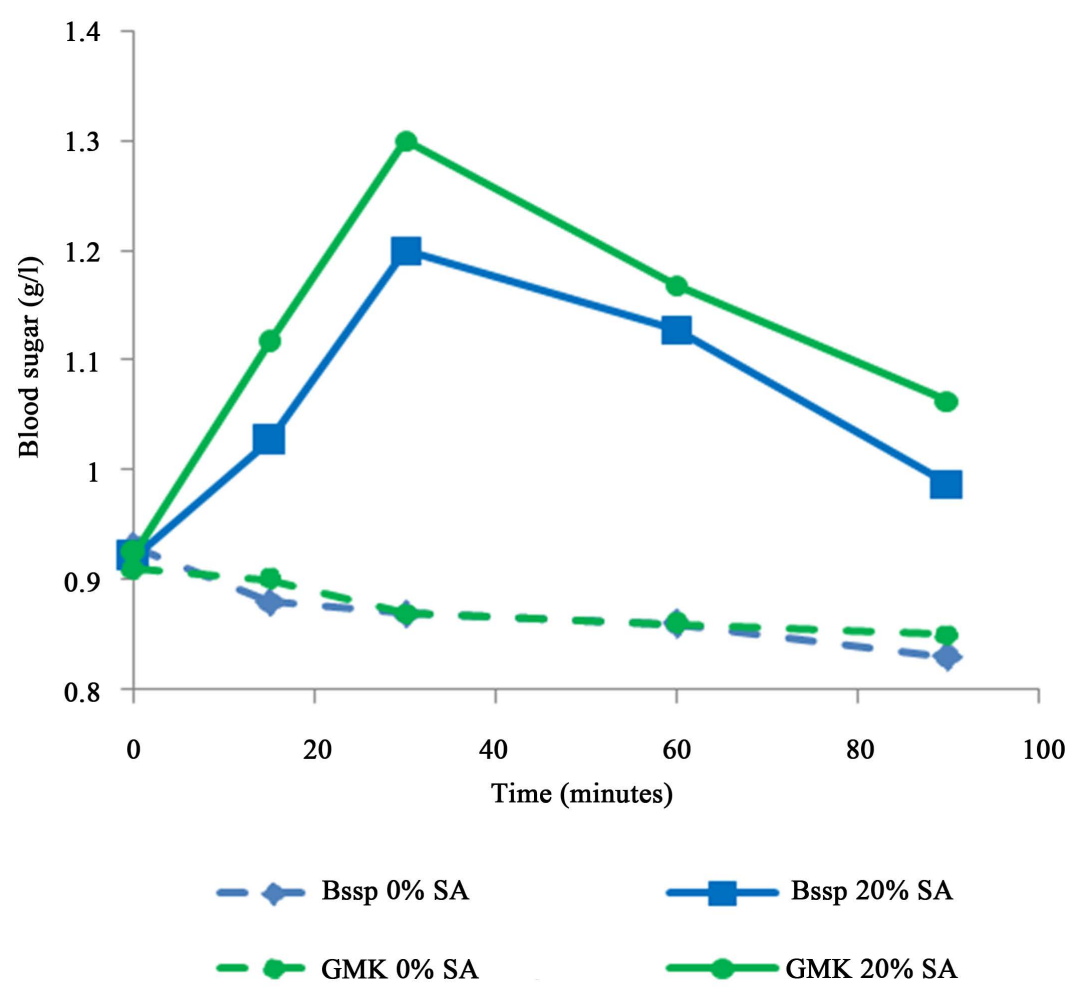

(a)
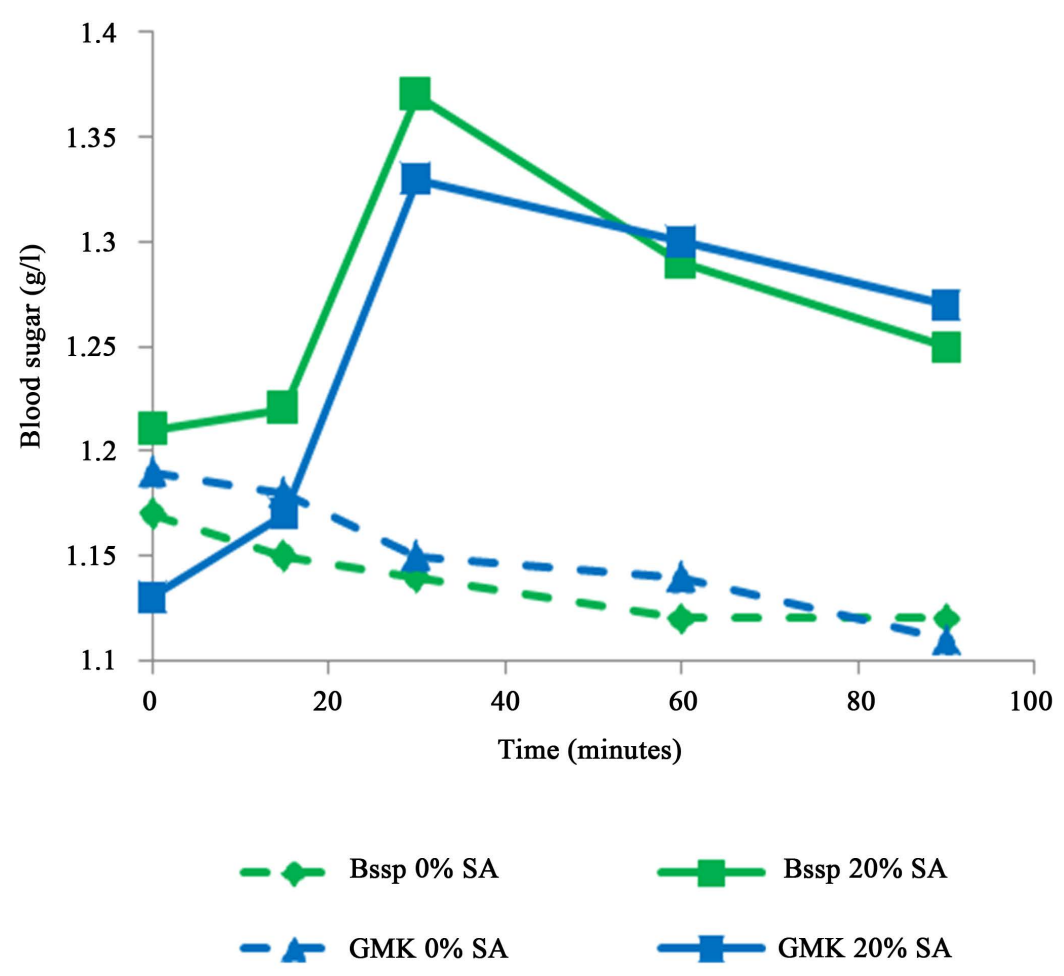

(b)

Figure 1. Evolution of postprandial blood glucose after consumption of liquids sweetened foods with healthy subjects (a) and pre-diabetics subjects (b). GMK SA $=0 \% 0 \%$ ginger juice added sugar; GMK SA $20 \%=20 \%$ added sugar juice; OPHS SA $=0 \%$ infusion of hibiscus $0 \%$ added sugar; $\mathrm{SA}=20$ OPHS infusion of hibiscus $20 \%$ added sugar. 
Table 2. Sugary foods frequently consumed during the period of Ramadan in Côted' Ivoire.

\begin{tabular}{|c|c|c|c|c|c|}
\hline & & \multirow{2}{*}{$\begin{array}{l}\text { Percentages of } \\
\text { people who } \\
\text { consume }\end{array}$} & \multirow{2}{*}{$\begin{array}{l}\text { Amount of } \\
\text { added } \\
\text { refined sugar }\end{array}$} & \multicolumn{2}{|c|}{$\begin{array}{c}\text { Place of } \\
\text { consumption }\end{array}$} \\
\hline & & & & Home & Out home \\
\hline \multirow{9}{*}{ Liquid food } & Bissap & $75 \%$ & $20 \%-35 \%$ & $55 \%$ & $45 \%$ \\
\hline & Ginger juice & $60 \%$ & $20 \%-35 \%$ & $53 \%$ & $47 \%$ \\
\hline & Tomi & $15 \%$ & $20 \%-35 \%$ & $30 \%$ & $70 \%$ \\
\hline & Juice Passion & $05 \%$ & $20 \%-35 \%$ & $80 \%$ & $20 \%$ \\
\hline & Zoumkoum & $08 \%$ & $20 \%-35 \%$ & $30 \%$ & $70 \%$ \\
\hline & Soda & $22 \%$ & - & $70 \%$ & $30 \%$ \\
\hline & Coffee shop & $70 \%$ & $10 \%-15 \%$ & $99 \%$ & $01 \%$ \\
\hline & Tea & $45 \%$ & $10 \%-15 \%$ & $98 \%$ & $02 \%$ \\
\hline & Herbal teas & $10 \%$ & $10 \%-15 \%$ & $98 \%$ & $02 \%$ \\
\hline \multirow{4}{*}{ Semi-liquid food } & Millet porridge & $85 \%$ & $15 \%-20 \%$ & $59 \%$ & $41 \%$ \\
\hline & Mush & $30 \%$ & $15 \%-20 \%$ & $15 \%$ & $85 \%$ \\
\hline & Rice porridge & $15 \%$ & $15 \%-20 \%$ & $95 \%$ & $05 \%$ \\
\hline & Quaker & $05 \%$ & $15 \%-20 \%$ & $100 \%$ & $0 \%$ \\
\hline \multirow{2}{*}{ Solid food } & Womi & $85 \%$ & $15 \%-20 \%$ & $25 \%$ & $75 \%$ \\
\hline & date & $85 \%$ & - & $25 \%$ & $75 \%$ \\
\hline
\end{tabular}

"bissap" Hibiscus sabdariffa juice; "Tomi" tamarind juice; "zoumkoum" made from millet and rice juice; "Womi" millet cakes

and 30 and 90 minutes after ingestion. In healthy subjects, the plasma glucose concentration increased from $0.9 \mathrm{~g} / \mathrm{L} \pm 0.07$ to $0.85 \mathrm{~g} / \mathrm{L} \pm 0.03$ and from $0.93 \mathrm{~g} / \mathrm{L}$ \pm 0.05 to $0.83 \mathrm{~g} / \mathrm{L} \pm 0.03$ respectively after ingestion of $0.5 \mathrm{l}$ of sugar-free ginger juice and $0.5 \mathrm{l}$ of sugar-free bissap juice. During the first 30 minutes after ingestion of juices to which sugar was added, blood glucose curves tend to increase with a peak difference, higher in pre diabetic subjects than in healthy subjects. For periods ranging from 30 to 90 minutes, the positions of the curves drop and the blood glucose curves according to the two juices decrease significantly.

\subsection{Postprandial Blood Glucose in Sweet Semi-Liquid Foods}

Curves of glucose kinetics induced after ingestion of millet slurry and corn porridge showed an increase in postprandial blood glucose levels during the period of 0 to 30 minutes and a fall in blood glucose levels during the period $30-90$ minutes in both healthy subjects and pre diabetic subjects (Figure 2). This increase in blood glucose is greater after ingestion of sweetened millet slurry and sweet corn porridge and more pronounced in pre-diabetic subjects. In healthy subjects, the plasma glucose concentration increased from $0.88 \mathrm{~g} / \mathrm{L} \pm 0.05$ to 1.26 $\mathrm{g} / \mathrm{L} \pm 0.03$ and from $0.89 \mathrm{~g} / \mathrm{L} \pm 0.09$ to $1.29 \mathrm{~g} / \mathrm{L} \pm 0.0630$ minutes after ingestion of $250 \mathrm{cl}$ of millet slurry and corn porridge with $20 \%$ added sugar. In pre 

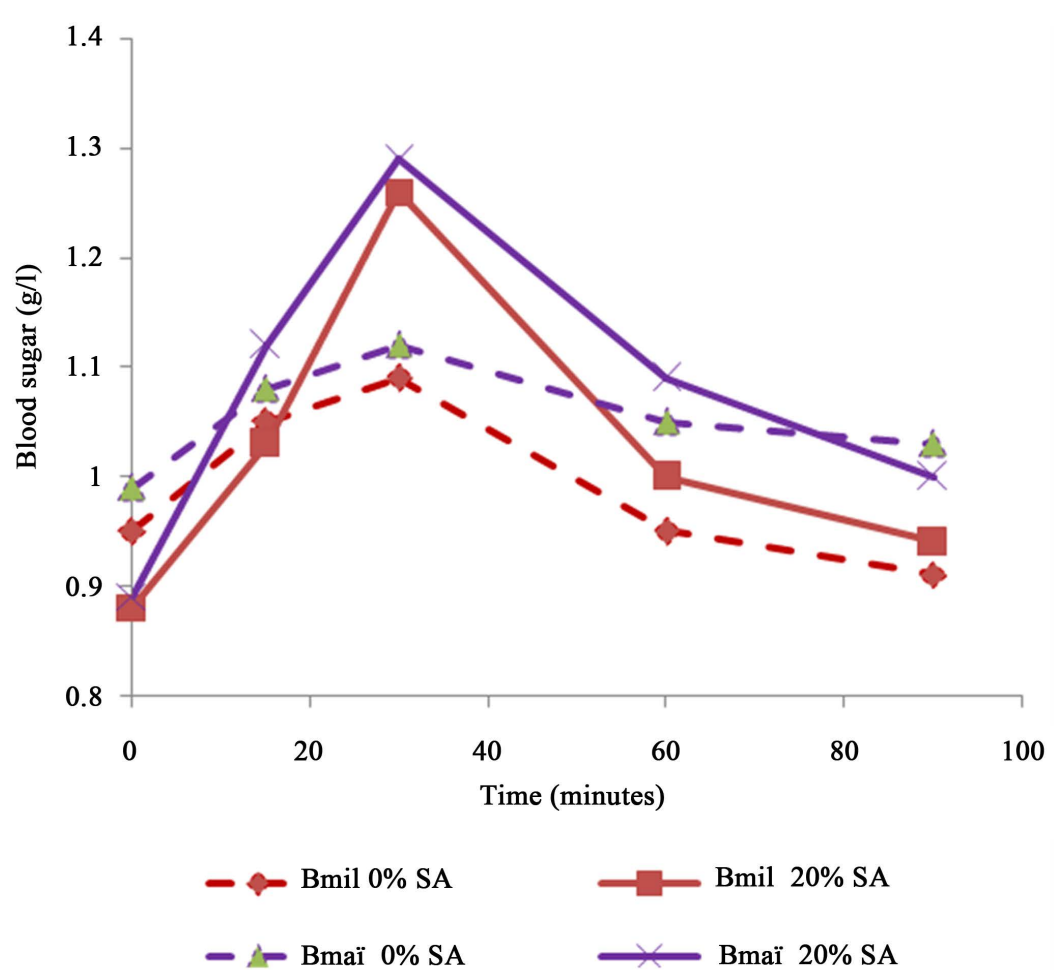

(a)
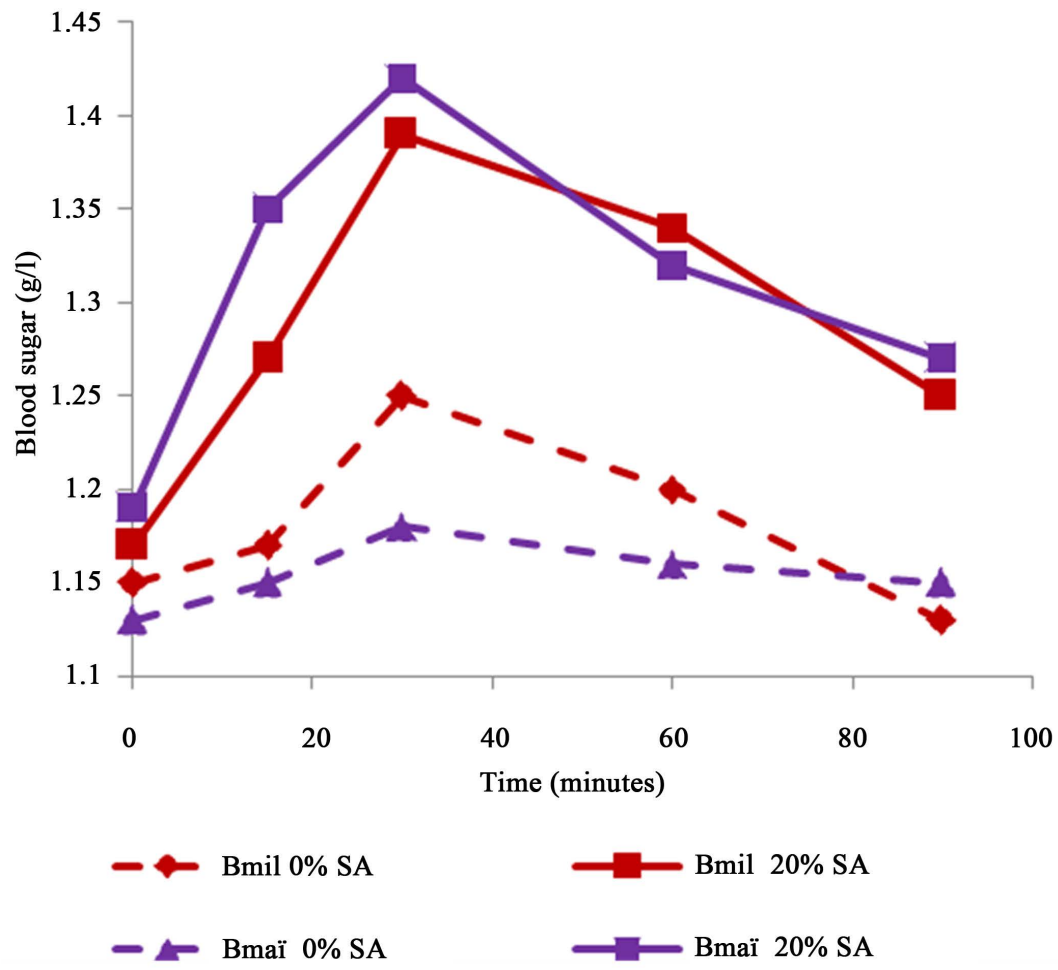

(b)

Figure 2. Evolution of postprandial after food consumption semi sweet liquids with healthy subjects (a) and pre subjects diabetes (b). BMIL SA $=0 \%$ Millet porridge added sugar; BMIL SA $=20 \%$ Millet porridge $20 \%$ sugar; Bmaï SA $=0 \%$ corn Bouille $0 \%$ added sugar; $20 \%$ corn boil corn Bouille $\mathrm{SA}=20 \%$ added sugar. 
diabetic subjects, it decreased from $1.17 \mathrm{~g} / \mathrm{L} \pm 0.05$ to $1.39 \mathrm{~g} / \mathrm{L} \pm 0.11$ and from $1.19 \mathrm{~g} / \mathrm{L} \pm 0.04$ to $1.42 \mathrm{~g} / \mathrm{L}$ respectively \pm 0.08 after the first 30 minutes.

\subsection{Postprandial Blood Glucose from Sweetened Solid Foods}

Figure 3 shows the postprandial kinetic response of glucose after consumption of "womi" (at $0 \%$ and $20 \%$ of added sugar), fresh and dry dates by healthy subjects and pre diabetic subjects. The glucose curves show a significant interaction

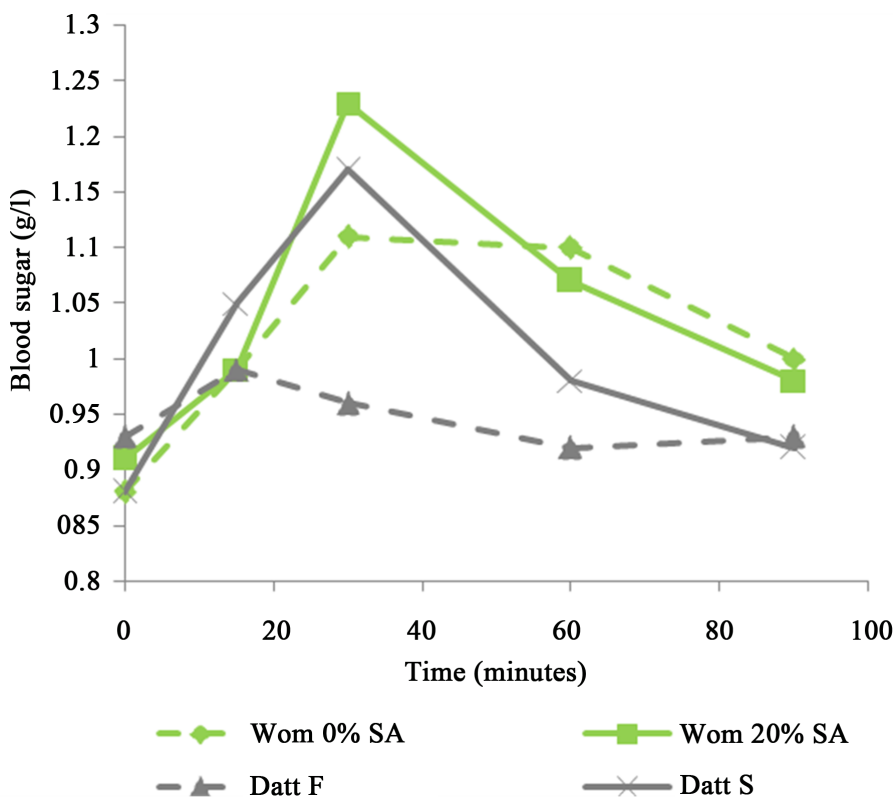

(a)

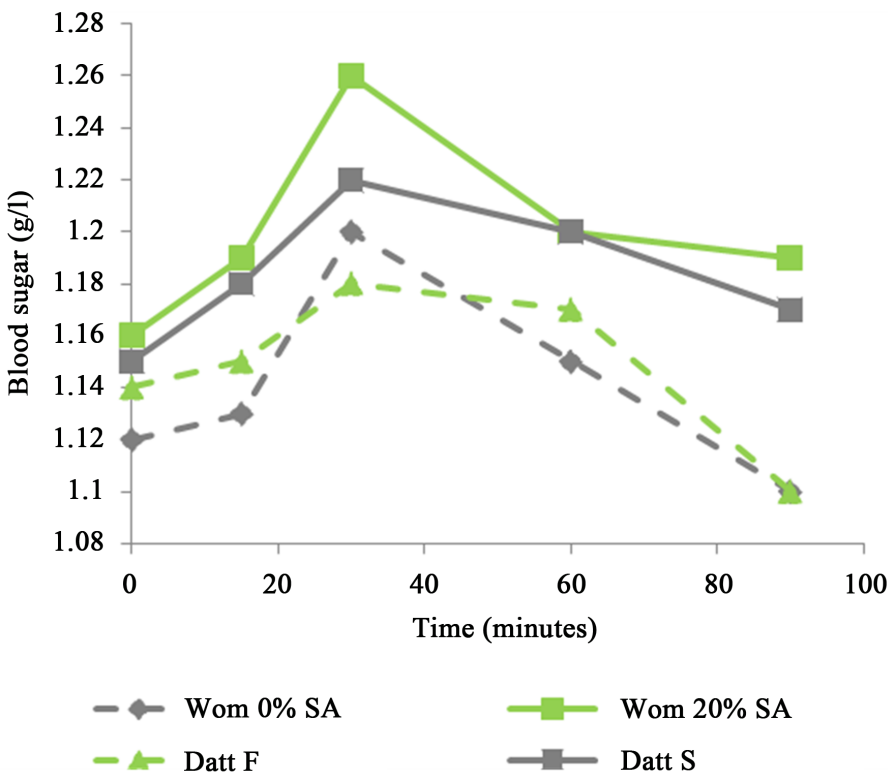

(b)

Figure 3. Evolution of postprandial after food consumption sweet solids healthy subjects (a) and pre diabetes subjects (b). Wom SA =0\% Womi added sugar; Womi 20\% Womi SA $=20 \%$ sugar; Datt $F=$ fresh Datte; Datt $S=$ dry Datte. 
between the sweet solid food and the time on the glycemic response. It results in the difference in the kinetics of glucose induced after ingestion of the "wom" $i$ and the dates. The plasma glucose concentration increased from $0.91 \mathrm{~g} / \mathrm{L} \pm 0.10$ to $1.23 \mathrm{~g} / \mathrm{L} \pm 0.07$ and from $1.16 \mathrm{~g} / \mathrm{L} \pm 0.05$ to $1.26 \mathrm{~g} / \mathrm{L} \pm 0,10,30$ minutes after ingestion of 10 units of $20 \%$ "womi", respectively in healthy subjects and pre-diabetic subjects. Postprandial glycemia induced by the consumption of dry dates is significantly higher than that of fresh dates in both healthy subjects and pre-diabetic subjects. During the first 30 minutes after ingestion of the sugary juices, blood glucose curves tend to increase with peak difference, higher in pre diabetic subjects than in healthy subjects. For periods ranging from 30 to 90 minutes, curve positions drop and blood glucose curves for food decline significantly.

\section{Discussion}

This study assessed the risk of diabetes occurrence among Muslim populations after regular and substantial consumption of sugary foods during fasting Ramadan.

\subsection{Frequency of Consumption and Proportions of the Most Consumed Sugary Foods}

Liquid, semi-liquid and solid foods to which sugar is added are regularly consumed during the fasting month of Ramadan. In addition to fatty foods, this type of sweet food is much consumed because "fasters" are encouraged to eat during meals before dawn, large amounts of foods high in fat and carbohydrates can provide them with enough "Energy for several hours". This would allow them to bear more easily this period of restriction. These same observations were made by [7]. This over-consumption of sweet foods has also been reported in the literature [1] [8], which showed that important changes in lifestyle and diet are observed during Ramadan fasting month both quantitatively and Qualitative in particular with a greasy and sweeter diet. Also, [9] reported that during this fasting period, the sugar that is among the most shared presents, is found as an ingredient for the making of several dishes.

\subsection{Postprandial Blood Sugar-Free Foods}

The consumption of ginger juice and bissap infusion without added sugar did not lead to an increase in blood glucose. However, ingestion of millet, corn and sugar-free womi intake resulted in increased blood glucose levels in both healthy and pre-diabetic subjects after 30 minutes. This difference in the hyperglycaemic power of foods can be explained by the nature of the foods studied. Indeed, [10] [11] [12] showed that postprandial blood glucose levels in food depend on the intrinsic and extrinsic characteristics of the food, in particular its nature, the way it is cooked, its physical state and the physico-chemical structure of its food. Nutrients and their interaction. Because millet and maize used in the preparation of 
porridge and "womi" are cereals naturally higher in carbohydrates than ginger rhizomes and Hibiscus calyces, digestion would have resulted in a higher blood glucose rise because of carbohydrates. The gelatinization of the starch contained in these cereals would also have contributed to a greater rise in the postprandial glycaemia of these slurries. Indeed, [13] [14] showed that in gelatinized form, the hydrolysis of starch by amylases, is much easier, resulting in a greater production of simple sugars. Even without added sugar, millet, maize and womi porridge, therefore, cause some hyperglycemia due to their intrinsic sugar composition and cooking.

\subsection{Postprandial Blood Sugar Glucose with Added Sugar}

The addition of commercial sugar into the juices, porridge and womi caused a significant rise in blood glucose levels during the first 30 minutes following ingestion, followed by a gradual decrease in blood glucose over time. This increase in blood glucose levels was $0.43 \mathrm{~g} / \mathrm{L}$ and $0.33 \mathrm{~g} / \mathrm{L}$ for bissap and ginger juice; $+0.38 \mathrm{~g} / \mathrm{L}$ and $+0.40 \mathrm{~g} / \mathrm{L}$ for millet and maize slurries; $+0.12 \mathrm{~g} / \mathrm{L}$ for the sweet womi. The increase in blood glucose after ingestion of sweetened juices is mainly due to the degradation of sucrose added in these juices to fructose and glucose, which are fast simple sugars that pass directly into the blood to increase the plasma glucose level. As for the increase in blood glucose after ingestion of sweetened porridge and womi, it would be the combined action of the digestion of the starch contained in the cereals and the sucrose added to the preparation. Indeed, as soon as these foods are ingested, several digestive enzymes, including salivary $\alpha$-amylase, pancreatic amylase, lactase, maltase, $\beta$-fructosidase, etc., hydrolyze throughout the gastrointestinal tract, Starch and sucrose in simple sugars (fructose but especially glucose) which pass directly into the blood through the small intestine, thus leading to a significant rise in blood sugar [15]. This increase in blood glucose is all the more important as the quantity of the products of this hydrolysis is high. This would explain the differences in amplitude of peaks in blood glucose observed after consumption of these various sugary foods. The gradual fall in blood glucose levels observed after the first 30 minutes would be due to a combined action of the liver and pancreas through a mechanism triggered in response to postprandial hyperglycemia induced by the ingestion of these foods to re- homeostasis. Indeed, during their passage in the blood at the level of the duodenum and the jejunum, the simple sugars resulting from the digestion of these juices and these porridges are transported by the portal vein to the liver where $35 \%$ to $65 \%$ of the glucose Is stored as glycogen [16] causing a significant decrease in blood glucose. Subsequently, hepatic stimulation of the pancreas would have produced insulin production, proportional to the amount of assimilated sugar. This hypoglycaemic hormone synthesized by the $\beta$-pancreatic cells makes it possible to increase the capture of plasma glucose by the adipocytes, the muscular cells and the cells of the liver [17] in order to use it in the metabolism of these cells. This led to a gradual decrease in blood sugar 
level, which stabilized on average around $1 \mathrm{~g} / \mathrm{l}$. Regarding the consumption of dates, the results showed that ripe dates bring about 5 times more sugar than fresh dates. This is due to their richness in simple sugars that are directly assimilable (sucrose, fructose and glucose) during ripening [18]. Repeated hyperglycemia after consumption of these various sugary foods during this fasting period is mainly the result of the amount of sugar added.

\subsection{Postprandial Blood Glucose in Healthy Subjects and Fasting Diabetic Subjects}

Comparative study of postprandial blood glucose trends in healthy subjects and pre-diabetic subjects showed that postprandial blood glucose levels in pre-diabetic subjects increased more rapidly than healthy subjects after ingestion of the sweet foods studied. This difference in glucose kinetics may be explained by peripheral cell insulin resistance, hypo insulinemia, and increased liver glucose production in pre-diabetic subjects [19] [20] [21]. Indeed, since the pancreas of the pre-diabetic subjects is made up of altered beta-cells, it is no longer able to produce enough insulin to effectively regulate postprandial hyperglycaemia. As a consequence, the increase in blood sugar levels is above normal [22]. Regular consumption of sugary foods by pre-diabetic subjects throughout the month of Ramadan fasting period is a real risk factor for increasing the rate of onset of diabetes in this population. [23] [24] have even estimated that $8 \%$ to $15 \%$ of prediabetics worldwide develop type 2 diabetes every year, the fasting of pre-diabetic Muslims could also contribute to this increase because their status is asymptomatic.

\section{Conclusion}

This study shows that among populations surveyed during Ramadan fasting period in Côte d'Ivoire, some are at risk of diabetes, including a family history of diabetes $(15.46 \%)$ and undiagnosed pre-diabetes (8.26\%). These people regularly engaged in this month like other fasters, with a high consumption of liquid, semi-liquid and sweet solids that cause regular hyperglycaemia, which can precipitate the onset of diabetes.

\section{References}

[1] Sebbani, M., El Ansari, N., El Mghari, G. and Amine, M. (2013) Apports alimentaires durant le mois de ramadan chez le patient diabétique de type 2 marocain. Eastern Mediterranean Health Journal, 19, 276-282.

[2] Farad-Bensenouci, S., Maillot, F. and Lamise, F. (2002) Les risques du Ramadan chez les sujets sains et les patients diabétiques. Cahiers de Nutrition et de Diététique, 37, 96-104.

[3] Roky, R., Houti, L, Moussamih, S., Qotbi, S. and Aadil, N. (2004) Physiological and Chronobiological Changes during Ramadan Intermittent Fasting. Annals of Nutrition and Metabolism, 48, 296-303. https://doi.org/10.1159/000081076

[4] Bener, A., Derbala, M.F., Al-Kaabi, S., Taryam, L.O., Al-Ameri, M.M., Al-Muraikhi, 
N.M. and Al-Mansoor, T.M. (2006) Frequency of Peptic Ulcer Disease during and after Ramadan in a United Arab Emirates Hospital. Eastern Mediterranean Health Journal, 12, 105-111.

[5] Gharmaoui, M. (2009) Sources d'information et représentations du jeûne du Ramadan chez les patients diabétiques musulmans. Etude qualitative auprès de dix-sept patients. Thèse pour le doctorat en medecine, Universtié Paris 7.

[6] IDF (Fédération Internationale du Diabète) (2006) Guide de prise en charge du diabète de type 2 pour l'Afrique subsaharienne. Zanzibar-Tanzanie, Fédération Internationale du Diabète-Région Afrique, 47.

[7] Mahmoud, A.I. (2007) Managing Diabetes during Ramadan. Clinical Care. Diabetes Voice, 52, 19-22.

[8] Magali, J. (2013) Ramadan et nutrition: Quelle nutrition. Nutrition Trends, 28-30.

[9] Diakhaté, D. (2011) Les pratiques sociologiques du jeûne chez les musulmans sénégalais. Monographie, 1-8.

[10] Pi-Sunyer, F.X. (2002) Glycémie Index and Diseases. The American Journal of Clinical Nutrition, 76, 290S-298S.

[11] Brand-Miller, J., Wolever, T.M.S., Foster-Powell, K. and Colagiuri, S. (2003) The New Glucose Revolution: The Authoritative Guide to the Glycemic Index-The Dietary Solution for Lifelong Health. Marlowe \& Company, New York.

[12] Nazare, J.-A. (2009) Modulation de la phase postprandiale du glucose. Human Health and Pathology. Thèse de doctorat en medicine, Université Claude Bernard, Lyon I.

[13] Eliasson, A.-C. (2004) Starch in Food: Structure, Function, and Applications. Woodhead Publishing Limited, 590 p.

[14] Jenkins, D.J.A., Wolever, T.M.S., Taylor, R.H., Barker, H.M., Fielden, H. and Baldwin, J.M. (1981) Glycemic Index of Foods: A Physiological Basis for Carbohydrate Exchange. The American Journal of Clinical Nutrition, 34, 362-366.

[15] Widmaier, E.P., Raff, H. and Strang, K.T. (2011) Vander's Human Physiology: The Mechanisms of Body Function. 12th Edition, McGraw-Hill Higher Education, New York, $784 \mathrm{p}$.

[16] Livesey, G., Wilson, P.D., Roe, M.A., Faulks, R.M., Oram, L.M., Brown, J.C., Eagles, J., Greenwood, R.H. and Kennedy, H. (1998) Splanchnic Retention of Intraduodenal and Intrajejunal Glucose in Healthy Adults. American Journal of Physiology, 275, E709-E716.

[17] Rinaldi, L. (2013) Impact de l'ajout de polysaccharides dans des matrices laitières gélifiées acides sur la digestion gastro-intestinale des protéines et des réponses métaboliques associées. Thèse de doctorat en Sciences et technologie des aliments, Université de Laval, Quabec-Canada.

[18] Makhloufi, A. (2008) Etude des activités antimicrobienne et antioxydante de deux plantes médicinales poussant à l'état spontané dans la région de bechar (Matricaria pubescens (Desf.) et Rosmarinus officinalis L) et leur impact sur la conservation des dattes et du beurre cru. Thèse de doctorat d'état en biologie Spécialité, Microbiologie et sécurité sanitaire des aliments, Université Aboubaker Belkaid.

[19] Gerich, J.E. (1996) Pathogenesis and Treatment of Type 2 (Noninsulin-Dependent) Diabetes Mellitus (NIDDM). Hormone and Metabolic Research, 28, 404-412. https://doi.org/10.1055/s-2007-979828

[20] Weyer, C., Bogardus, C., Mott, D.M. and Pratley, R.E. (1999) The Natural History of Insulin Secretory Dysfunction and Insulin Resistance in the Pathogenesis of Type 
2 Diabetes Mellitus. The Journal of Clinical Investigation, 104, 787-794. https://doi.org/10.1172/JCI7231

[21] Pratley, R.E. and Weyer, C. (2001) The Role of Impaired Early Insulin Secretion in the Pathogenesis of Type II Diabetes Mellitus. Diabetologia, 44, 929-945. https://doi.org/10.1007/s001250100580

[22] NIH (National Institute of Diabetes and digestive and Kidney Diseases) (2014) Insulin Resistance and Prediabetes. No. 14-4893, 1-20.

[23] Mac Callum, L. (2011) 5 Minute Medscholl. Prediabetes, 1-2.

[24] Santaguida, P.L., Balion, C. and Hunt, D. (2005) Diagnosis, Prognosis, and Treatment of Impaired Glucose Tolerance and Impaired Fasting Glucose. Summary, Evidence Report/Technology Assessment, No. 128.

Submit or recommend next manuscript to SCIRP and we will provide best service for you:

Accepting pre-submission inquiries through Email, Facebook, LinkedIn, Twitter, etc. A wide selection of journals (inclusive of 9 subjects, more than 200 journals)

Providing 24-hour high-quality service

User-friendly online submission system

Fair and swift peer-review system

Efficient typesetting and proofreading procedure

Display of the result of downloads and visits, as well as the number of cited articles

Maximum dissemination of your research work

Submit your manuscript at: http://papersubmission.scirp.org/

Or contact ojemd@scirp.org 